\title{
Article \\ Involvement in Renewable Energy in the Organization of the IR 4.0 Era Based on the Maturity of Socially Responsible Strategic Partnership with Customers-An Example of the Food Industry
}

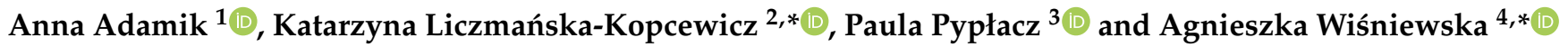 \\ 1 Faculty of Management and Production Engineering, Lodz University of Technology, 266 Piotrkowska Street, \\ 90-924 Lodz, Poland; anna.adamik@p.lodz.pl \\ 2 Faculty of Economic Sciences and Management, Nicolaus Copernicus University in Torun, Gagarina 13a, \\ 87-100 Torun, Poland \\ 3 Faculty of Management, Czestochowa University of Technology, Armii Krajowej 19B, \\ 42-201 Czestochowa, Poland; paula.pyplacz@wz.pcz.pl \\ 4 Faculty of Management, University of Warsaw, Szturmowa 1/3, 02-678 Warszawa, Poland \\ * Correspondence: kliczmanska@umk.pl (K.L.-K.); agnieszka.wisniewska@uw.edu.pl (A.W.)
}

check for

updates

Citation: Adamik, A.;

Liczmańska-Kopcewicz, K.; Pypłacz, P.; Wiśniewska, A. Involvement in Renewable Energy in the Organization of the IR 4.0 Era Based on the Maturity of Socially

Responsible Strategic Partnership with Customers-An Example of the Food Industry. Energies 2022, 15, 180. https://doi.org/10.3390/en15010180

Academic Editor: Wen-Hsien Tsai

Received: 21 November 2021

Accepted: 27 December 2021

Published: 28 December 2021

Publisher's Note: MDPI stays neutral with regard to jurisdictional claims in published maps and institutional affiliations.

Copyright: (C) 2021 by the authors. Licensee MDPI, Basel, Switzerland. This article is an open access article distributed under the terms and conditions of the Creative Commons Attribution (CC BY) license (https:// creativecommons.org/licenses/by/ $4.0 /)$.

\begin{abstract}
The purpose of this study is to explain the determinants of the process of investing in renewable energy sources (RES) from the perspective of enterprises, with particular emphasis on the strength of their orientation on such strategic issues as sustainable development, orientation towards innovation, as well as the level of maturity of their partnership with the client. The research method was carried out on a sample of 157 industrial enterprises in the food industry. The research process was conducted with the consideration of making these decisions dependent on the strength of companies commitment to several strategic issues: sustainable development, innovation orientation, and the maturity of their partnership with the customer. The results of the data analysis collected during the quantitative research show a strong correlation between the level of openness of the organization of the IR 4.0 era to RES and (a) orientation towards sustainable development, (b) orientation towards intelligence, and (c) maturity of strategic partnering with customers.
\end{abstract}

Keywords: renewable energy sources; sustainability; sustainable development; innovation; innovation orientation; partnership with the customer; maturity of strategic partnering with customers

\section{Introduction}

In the SMART WORLD era, which means the era of not only intelligent technological solutions from the field of Industry 4.0, but also socially and environmentally responsible sustainable development, the role of interorganizational cooperation is significantly growing, especially in terms of companies' ability to engage in various types of partnerships. Nowadays, partnerships involve taking into account the needs and creating close relations not only with business partners, but also with social and environmental ones. Maturity of partnership in each of these areas determines more and more strongly the market success of practically every contemporary organization, in practically every field of its activity. An especially relevant factor in recent years has been the ability to engage in strategic partnerships which are socially responsible, as in the emerging SMART WORLD, the significance of considering SDG (Sustainable Development Goals) [1] is systematically growing.

SMART WORLD means deliberate orientation towards creation and implementation of proactive and innovative technological solutions, which will shape better and better, and at the same time more humanitarian and balanced, environment and the conditions for social and economic functioning [2]. Hence, in the SMART WORLD, an intelligent combination 
of physical perception, cyber interaction, correlation of social and environmental space, and cognitive thinking takes place across all aspects of daily life [3,4].

Operating in such an environment forces the development of the so-called SMART organizations, which will base their philosophy on sustainable development and continuous knowledge management [5]. Their knowledge resources must be very broad and deepened significantly in customer, product, process, and environmental data. Thanks to this, smart organizations create and use more and more new solutions, not only technical and technological [6], but also social, organizational and environmental innovations [7]. This fits into the essence of the concept of "sustainable development", which boils down to their implementation of all processes to ensure high environmental, economic, social, and spatial standards of the entities cooperating with them, as well as future generations, in accordance with the principles of intra- and inter-generational capital. In this way, their development is sustainable development "that meets the needs of the present without compromising the ability of future generations to meet their own needs"(Report of the World Commission on Environment and Development: Our Common Future). This direction of change has been set by growing social awareness. Due to the requirements accompanying these processes, organizations operating in the era of the reign of Industry 4.0 (IR 4.0) must become not only innovative, but also sustainable [8]. There are, of course, many ways to move in this direction. An especially effective approach seems to combine organizations intelligent, socially responsible innovativeness with improving their openness to strategic partnerships with different stakeholder groups.

Today, when designing a set of cooperation ties necessary for the effective development of an enterprise, one should take into account the selection for alliances of appropriate partners related to the company's key skills, markets, or technologies. Collaboration, especially close ones, should be established, primarily with customers. In the S\&S WORLD, their decisions, their choices, their market behavior are becoming more and more socially and environmentally conscious, and thus they are beginning to determine in a specific way the strategies of enterprises. They directly enforce specific orientations of their development. Therefore, the role of proper understanding of the customer, and especially of how the customer perceives and evaluates specific market behaviors of contemporary organizations, is growing critically. This is more important because the partnership with the customer requires many different investments, including modern technologies, socially and environmentally responsible solutions, time and managerial resources. Misdirected investments mean unsuccessful projects and lost benefits and often high costs.

A good deal is written about customer requirements as to the quantity, quality, prices, distribution channels, or methods of promoting products in various industries $[9,10]$, or about the customer's assessment of the CSR activities of modern enterprises [11]. However, we still know too little about how customers perceive their role and the possibility of active, partner participation in these processes [12,13]. This state creates a significant research gap.

Therefore, it seems strategically important to identify what determines the possibility of entering into a mature partnership with customers by companies, as well as what, in the broad sense of the term, benefits may be derived from engaging in this type of relationship. It is about both aspects important from the perspective of the customer, business and the environment (sustainable development).

Due to a commonly growing awareness of global social-environmental problems and Sustainable Development Goals 2030 (2030 Agenda for Sustainable Development), an increasing number of companies see the necessity of getting involved in CSR and pro-environmental changes.

The literature describes many forms of their activity in this area [14,15], one of which is RES involvement [16,17]. Unfortunately, there are still no studies that would answer the question to what extent companies receive genuine support from clients in these processes. This is another diagnosed research gap, the importance of which is emphasized by $[16,18]$. The results of a study conducted by Cyfert et al. [19] suggest that after the COVID-19 
crisis, there will be an increase in the use of Industry 4.0 era solutions supporting the increased importance of economic, social and environmental dimensions of corporate social responsibility. These authors, suggest a stronger link between management solutions (Industry 4.0 era solutions) and corporate social responsibility, which may mean an increase in companies' openness to RES investments, socially and environmentally sustainable corporate innovation, and maturity of partnerships with customers.

Therefore, one of the key activities today will thus become the willingness to use sustainable energy and RES. There is also another third research gap in this respect. While a lot is written about the importance of RES, methods, technologies of their use, or problems related to financing this type of investment [20-22] (which constitutes the hard conditions for this type of activity), we still know little about the "soft" aspects related to its exploitation. One of them is the perception of this type of activity by clients of the company's implementing RES, or the customers' willingness and forms of supporting such companies (real maturity of the company's partnership with its clients). There are also gaps in the descriptions and analyzes of the determinants of the effectiveness of this type of investment.

Seeking to contribute to the clarification of the three research gaps indicated above as the aim of this study is to explain the determinants of the process of investment in renewable energy sources (RES) by enterprises, with particular emphasis on the strength of their orientation on such strategic issues as sustainable development, innovation orientation, as well as the level of maturity of their partnership with the customer. The novelty of the research undertaken is not only the linking of the above-mentioned strategic issues into one construct but also the orientation of the research to a specific industry. The conclusions from the conducted research have a chance to support and guide entrepreneurs in making decisions about investing and methods of implementing and operating investments in RES. On the one hand, the results of the research clarify what is necessary to implement such investments more efficiently. On the other hand, the benefits of this type of activity are indicated.

In order to investigate these themes empirically, food companies operating in Poland were selected for quantitative research. The results indicate a strong correlation between producers' willingness to invest in RES and (a) their orientation toward sustainability, (b) their orientation toward innovation, and (c) their customer partnership maturity. Companies investing in RES that realistically implement sustainable development and socially responsible innovation, are supported and appreciated by mature partnerships with customers.

\section{Literature Review}

\subsection{Significance of Investments in RES}

A sustainable economic system is aimed at long-term and multifaceted sustainability [23], and its development is to be based on the principles of economic prosperity, social equality, and environmental integrity [24-27] (WCED 1987). Current market trends and global problems motivate companies to implement sustainable business models [28]. Adherence to the principle of environmental integrity is to ensure that the actions of current generations do not take away the future right to use clean natural resources such as land, water, and air [29-32]. Due to dwindling natural resources, climate change, and environmental devastation, renewable energy sources often also called alternative energy sources seem to be a way to solve many problems [33]. This justifies the growing interest of governments and economies in replacing traditional energy sources, which are at odds with sustainability goals, with new renewable ones that are inexhaustible and minimize their ecological footprint [34-37].

Sustainable development can be seen as development that incorporates social, environmental, and economic considerations, which occurs to increase the well-being of current generations without causing a decline in the well-being of future generations [38]. The idea of sustainable development has been transferred to the field of energy, thanks to which the term Sustainable Energy Development (SED) has been created and is now in use. The fundamental principle of SED is the efficient use of energy, human, economic 
and natural resources $[16,39]$. The study of factors influencing SED, such as methods or characteristics of energy consumption, is becoming increasingly important. Countries with higher levels of human development tend to emit more $\mathrm{CO}_{2}$ per capita and generally have greater environmental problems [40]. As a consequence, the concept of balanced consumption at all levels, including in terms of one's working and private life, has gained a great deal of interest from researchers [41].

Regarding the much-discussed SED, renewable energy sources (RES) can provide energy services with zero or near-zero emissions of air pollutants and greenhouse gases. Thus, investing in the development of a renewable energy system will make it possible to solve today's most important tasks, such as: improving the reliability of energy supply and saving organic fuels, solving the problems of local energy and water supply, raising the standard of living and level of employment of the local population, ensuring sustainable development of remote regions in desert and mountain areas, meeting countries' obligations to comply with international agreements on environmental protection [42,43]. The idea of SED is striving for compromise between human interference in the environment related to, among others, economic development and preservation of its natural assets [16].

Energy policy is one of the key features of European integration. Three main issues should be emphasized here: market deregulation, energy security, and climate change. Renewable energy that enables the transition to a low-emission economy is at the core of the European Union's energy and climate change package [44]. EU Member States have specific targets currently set for 2021-2030. Germany is considered a forerunner in the EU with regard to renewable energy, having already become the world leader in terms of installed wind power capacity in 2003. Many other countries have also made great advances in this field, and the RES culture has become tangible in practice $[45,46]$.

In Poland, the country where the empirical research has been carried out for this study, the situation in terms of RES use is not yet favourable, but positive changes are noticeable. According to the report of the President of the Energy Regulatory Office in Poland, in recent years the structure of electricity generation in Poland has been changing in favor of renewable sources (an increase from 7\% in 2016 to 9\% in 2019 in the total national generation). At the end of 2019, the capacity of all renewable energy sources in the power system will exceed $9 \mathrm{GW}$ (about $163 \mathrm{MW}$ in small RES installations and more than $1 \mathrm{GW}$ in micro-installations (including prosumer ones) [47].

One of the key reasons for such a significant increase in the importance of RES is changes in customer awareness and attitudes. Customers, having access to reliable and up-to-date information, start to pay more attention to the organisation's methods of operation, including its social usefulness and environmental responsibility [11]. Thus, when managing an organization, it is necessary to keep in mind that an organization operating in a free market economy system also has other types of functions and tasks to fulfill, other than maximization of profits. The relationship between RES, sustainable development and the role of the customer is so strong that it should be considered together. This relationship means that today it should be taken into account in terms of setting long-term goals for virtually any organization [48]. This is because all renewable energy activities implemented consequently/finally concern processes or product solutions that ultimately relate to the customer and the customer's perception of the organization's activities [16]. Therefore, recognizing the customer as an important element of the organization's strategy is crucial today.

\subsection{Customer Partnership Maturity}

The strategic partnership is a management approach used by two or more organizations to achieve specific goals by increasing the effectiveness of each participant's resources. It requires an open, trusting relationship between partners to achieve common goals [49]. The partnership is a model of relations between partners, including: cooperation and collaboration, equality of rights and duties, respect of autonomy and otherness, tolerance. 
While generally preserving their individuality, partners in such relationships voluntarily accept mutual interdependence in certain areas [50].

Strategic partnerships of enterprises concern conduct, both in internal relations (developed between owners, between owners and employees, or between employees) and external relations (developed in associations with suppliers, customers, competitors, social and public organizations). Observation of how and on which levels an organization is able to establish ties of partnership cooperation allows, to some extent, to conclude its sustainable development, maturity and long-term competitiveness [7]. This is because, as a rule, companies that successfully manage this type of relationship thanks to the support of partners, perform better in the market, are able to generate more dynamic development [51-53], generate a wider range of benefits from cooperation than others [24,54]. As a result, many of them change their technologies and markets faster and more creatively than others [55], and in addition gain not only much higher profitability but also higher value, e.g., of shares [56], significant revenue growth [57] and competitive advantage [58,59]. Due to the above, and the significant costs accompanying this type of relationship, e.g., costs of social security, investment in environmental protection, or CSR and Corporate Governance tools, as well as other organizational efforts, partnerships should be a carefully considered part of the strategy of any modernly managed company [60].

In the course of their research, Y.L. Doz and G. Hamel have proved that the highest willingness to behave in partnership can be expected from highly innovative and creative companies in their approach to challenges [61]. Being open to cooperation and making optimal use of their core competencies, they usually strive to achieve unique, functional goals. In order to anticipate customer needs, they are ready for continuous learning. Thanks to such behavior, partnerships lead them to synergies of inter-organizational activities, which increase the partners' efficiency in relation to other competitors and give them above-average results and profits, both financial and non-financial [62].

Given the objectives of this study, strategic partnerships with customers, a particular type of external relationship, seem particularly relevant. Companies seeking to achieve market success must not only allocate their internal resources efficiently, but also pay attention to external stakeholders, in particular customers [9,63]. A customer partnership is usually defined as a formalized working relationship between a customer and a manufacturer that involves performing coordinated development activities to develop and deliver a new product. The goal of this partnership is to "produce improved mutual outcomes or single outcomes with expected reciprocity over time" [61,62].

Worldwide research provides strong evidence that obtaining more market information from customers and, in some cases, even involving customers directly in development teams leads to more effective creation and implementation of new products [12]. Amara and Landry [64] note that the customer as a source of information brings several benefits to firms. When innovations are implemented, ideas with customer input have higher levels of novelty and fit. Tether [65] further states that collaboration with customers can be particularly beneficial when the goal is to develop novel or radical innovations.

Its effectiveness can be seen particularly in the increase in the success rates of new products and increasingly efficient acquisition of market information necessary to design improvements to existing products [66]. It is also used to generate new, more innovative ideas or new ways of combining previously available resources. Different types of knowledge (each partner's knowledge) are combined in such partnerships. In this way, customer feedback, customer interaction, and buyer participation in the process of new product development often significantly improve the competitive position of companies $[10,67,68]$. The research conducted by Liczmańska-Kopcewicz and team indicates a rather strong relationship between the range of exploration and the level of exploitation of buyers' knowledge and the achievement of product innovation goals [9].

The processes of creating and then shaping partnerships between companies and their customers can be viewed in different ways [69]. They can also be analyzed in different ways. A measure of partnership evaluation can be its maturity. The more areas it involves and 
the more advanced the partnership with customers is, the more mature it is. This means that it has a higher degree of comprehensiveness and quality of preparation to perform the related tasks and to achieve the objectives set in this area [7].

In order to somehow assess the level of a given company's involvement in the development of its partnership activities with the customer, A. Adamik suggests evaluating the level of activity and maturity of partnership bonds. The "scale for assessment of strategic partnership of enterprises" with its specific values may be helpful in identifying this level. Recognizing that partnership in particular areas may be absent, very weakly, weakly, moderately, strongly or very strongly visible/active, it can be assessed, e.g., on a scale of 1-5. A description of the levels of assessment of both activity and maturity of strategic partnership is presented in Table 1. The parameters of partnership with the customer evaluated on this scale may be, e.g.:

- $\quad$ bilateral nature of cooperation, meaning both acquisition or transmission of information (symmetry of benefits),

- the durability of relations, meaning that a company forms lasting relations with customers,

- quality of communication, meaning that a company has an effective system for communication with customers,

- $\quad$ understanding of needs, meaning that a company has vast knowledge of its end-consumers,

- frequency of contacts, meaning that a company is involved in cooperation with customers.

Table 1. Levels of activity and maturity of strategic partnership proposed for the purpose of evaluation of the areas of customer partnership.

\begin{tabular}{cl}
\hline & \multicolumn{1}{c}{ Description of the Level of Strategic Partnership } \\
\hline 1 & $\begin{array}{l}\text { Level of activity } \\
\text { practice of the company's functioning }\end{array}$ \\
\hline 2 & $\begin{array}{l}\text { Fairly numerous partnership parameters, but rarely visible in the practice of the } \\
\text { company's functioning }\end{array}$ \\
\hline 3 & $\begin{array}{l}\text { Fairly numerous partnership parameters, frequently noticeable in the practice of the } \\
\text { company's functioning }\end{array}$ \\
\hline 4 & $\begin{array}{l}\text { Partnership parameters both numerous and frequently noticeable in the practice of } \\
\text { the company's functioning }\end{array}$ \\
\hline 5 & $\begin{array}{l}\text { Partnership parameters very numerous, strongly and frequently noticeable in the } \\
\text { practice of the company's functioning }\end{array}$ \\
\hline Very low & $\begin{array}{l}\text { Rudimentary involvement in creating inter-organizational partnership bonds; } \\
\text { very low levels of activity diagnosed in the field of customer partnership }\end{array}$ \\
\hline Low & $\begin{array}{l}\text { Lower than standard involvement in creating inter-organizational partnership } \\
\text { bonds; low levels of activity diagnosed in the field of customer partnership }\end{array}$ \\
\hline Source: Adamik A. Partnerstwo strategiczne a konkurencyjność przedsiebiorstw. Perspektywa MSP, Zeszyty \\
Lódź 2015.
\end{tabular}

The favorable attitude of consumers toward mature strategic partnerships may be a rationale for many entities to build competitive advantage in cooperation with customers, based on various types of mutually beneficial investments in process innovations, among others. Such investments may be RES [16,70-72]. There is a growing indication that 
consumers should share responsibility for environmental degradation [18], as it is to meet their needs that producers act [73]. Therefore, their support of producers in proenvironmental spheres must be more visible. The partnership means bilateral actions (involvement of each partner in the relationship).

Consumer support for brands investing in renewable energy sources should be manifested primarily by consistent purchase choices in favor of such brands, but also by sharing costs by accepting a higher price and by recommending the RES-based brand [74-76] Since consumers' propensity to behave in a certain favorable way toward a brand stems from appropriately shaped cognitive and emotional attitude components [77,78], and according to goal-directed behavior theory, such intentions are shaped by the influence of the cognitive and emotional component [79], strategic partnerships with them can be an important catalyst for widespread openness to RES.

Addressing sustainability challenges requires an innovation infrastructure inclusive of users [80]. Due to the fact that consumer choices determine what is delivered to the market and how it is delivered [81], consumer support for sustainable companies is important, not only for the "visible" values created by them, directly related to the product, but also for process innovations, which are, for instance, alternative energy sources.

So far, much has been written about the benefits of partnerships with customers in the creation of innovations [63-65,67,82,83], yet, unfortunately, there is still little empirical evidence of the impact of such collaborations on companies' propensity to invest in renewable energy resources (RES). In order to contribute at least to some extent to the development of research in this area, the research process described in this paper chose as an object of study the companies from the food industry sector functioning in Poland, with the following research hypothesis being formulated:

Hypothesis 1 (H1). There is a positive dependence between the orientation of food industry companies toward customer partnership maturity and their involvement in RES.

\subsection{Orientation toward Innovations and Sustainable Development as Antecedents of Customer Partnership}

Innovation is widely regarded as a key success factor for companies and a necessary condition for their growth, as recognized by both market practitioners and theorists [84-86]. Introduced innovations, whether visible (e.g., product or marketing innovations) or invisible to the end consumer (e.g., organizational or process innovations) result in strengthening the competitive position by attracting new customers and retaining existing ones. The ability to generate innovation is becoming more important than ever, enabling firms to build and maintain a competitive advantage in the face of intensely and dynamically changing consumer preferences and shorter product life cycles $[87,88]$. For innovations to succeed in the marketplace, a consumer-oriented perspective is essential in their design. The experts' perspective may be insufficient, detached from the real needs and expectations of the market, as it is focused more on the technical and functional perspective, while consumers accept innovations that fit their lifestyles and create new experiences for them [89]. Companies seeking to maximize financial returns from their ventures are making increasing use of knowledge and stakeholder engagement [90]. The literature on open innovation highlights the growing importance of R\&D efforts with external partners (in ecosystems) to successfully achieve desired innovative outcomes [91,92].

Customers' needs are changing as their lifestyles change, but also along with technological advances, which have clearly increased the pace of change in recent times [93]. Ongoing response to market changes, therefore, requires companies to be highly innovative. This characteristic refers to the nature/quality of an organization's capabilities, its openness to new ideas, and its willingness to invest (both money and labor) in new solutions [94]. Nowadays, it should be a lasting feature of organizational identity, which means that after initial success, an organization strives for further development through innovation [95], thus gaining consumer acceptance and strengthening relationships with consumers. 
An organization's innovativeness (especially technological innovation) involves the need to possess and continuously expand relevant knowledge, which is often limited by the company's resources and existing capabilities. This usually results in the exploration and exploitation of internal sources, as well as support from external sources (synergistic cooperation of companies, universities, research laboratories, as well as suppliers and customers) [96]; von Hippel 1988; Rothermael and Deeds 2006). Zakrzewska-Bielawska [97] argues that to overcome internal resource constraints, firms should make greater use of formal or informal partnership arrangements with other organizations to achieve their innovative goals. Research shows that the partnership approach develops best when the organization is open to continuous learning and future-oriented (Hult, Ketchen, and Nichols 2003). Thus, it is both innovative and SMART (smart) in its behaviors [98,99]. In this case, the partnership with the customer will exhibit higher maturity. Therefore, given the selected research sample, the following research hypothesis was put forward in the course of the study:

Hypothesis 2 (H2). There is a positive dependence between the level of smartness of companies from the food industry sector and customer partnership maturity.

Going further in the deliberations, innovation is considered a decisive factor in the creation of social wealth [100-102]. With this in mind, in the research undertaken by the author team and described below, it was decided to also verify the hypothesis stating that:

Hypothesis 3 (H3). There is a positive dependence between the level of smartness of companies from the food industry sector and their openness to investments in RES.

Sustainable development, in turn, refers to the social well-being, present and future needs of humanity, related to a wide variety of issues, which include climate issues, pollution and environmental degradation, in addition to issues of equality, peace, poverty eradication, among others $[14,15,27,103,104]$. This generally involves adherence to three key principles: the principles of environmental integrity, economic prosperity, and social equality $[25,27]$. Issues related to their implementation and enforcement are being studied by scholars from many different disciplines [105]. Academic contributions on this topic have so far been limited to observations of individual firms and how they should behave to limit their non-economic impacts. Today, however, more is needed, as the required sustainability is a process in which trade-offs are developed between the interests of the economy, the environment, and the society $[26,106]$. Sustainability-oriented decisions must result from collaboration between state administration, universities, business, and society. Only such an approach produces concrete and positive results. Research proves that in companies that use even only elements of CSR approach to introduce innovations, the chances for successful product and process innovations grow [102]. Besides, the role that social and environmental aspects, such as occupational safety, working conditions, and emissions, play in customers' purchasing decisions is increasingly highlighted in the literature $[107,108]$. Therefore, it was decided in the course of the research undertaken to also verify the hypothesis that:

Hypothesis 4 (H4). There is a positive dependence between the level of orientation of companies from the food industry toward Sustainable Development and their customer partnership maturity.

Popularizing and maximizing investments in renewable energy sources (RES) is one of the goals of global sustainable development (United Nations 2015). Therefore, it seemed necessary for the authors of the study to verify also the hypothesis to what extent food companies manifest such readiness within their sustainable development strategies. Therefore, the hypothesis was put forward that: 
Hypothesis 5 (H5). There is a positive dependence between the level of orientation of companies from the food industry toward Sustainable Development and their openness to investments in RES.

\section{Methodology}

Due to the adopted research goal, an analysis of domestic and foreign literature was carried out, as well as mind mapping. The authors, while working on the research, created a mind map [109], which was used as a tool for sharing work (electronic mind map prepared using the FreeMind software (Developer: Jörg Müller, Daniel Polansky, Petr Novak, Christian Foltin, Dimitri Polivaev, et al., GNU General Public License), which is especially important and brings many benefits when the authors live at considerable distances from each other. Mind maps were recognized by the authors as a heuristic method, thanks to which the thought process was more creative, broader, and enabled the generation of new ideas and modification of the existing ones.

This solution also showed the progress process. Cognitive methods were supported by own research. Statistical measurements and data analysis using pivot tables were used to analyse the results of own research. The work used a hypothetical-deductive method, which takes into account the specificity of empirical sciences and rejects inductivism in its assumptions [110]. This method was adopted due to the inability to objectively implement the induction method. The hypothetical-deductive method is based on two underpinning assumptions. The first states that all theorems appearing in science, including individual and also observational ones, are hypothetical and revocable. The purpose of scientific proceedings (the second assumption) is to eliminate false hypotheses by means of falsification.

The food sector that which produces goods that meet people's nutritional needs is one of the basic and rapidly developing sectors of the economies of countries around the world. It is highly diversified in terms of the profile of the processing activities carried out. It is made up of companies involved in the processing of animal products, processing of plant products, secondary processing and the production of stimulants. For this reason, the products of the food industry are both low-processed (animal slaughter, meat demolition) and are the result of advanced technological processes (e.g., freeze-dried food) [111]. Moreover, on the basis of macroeconomic data, it can be concluded that the food industry is characterized by exceptional stability and low sensitivity to fluctuations in the economic situation [112]. Businesses operating in the food sector are aware that competition in each category is very strong. Hence, the key to breaking through and achieving success is introducing innovations to the market, and earlier-their proper design and planning the entire process of their implementation.

In the research process undertaken, an attempt was made to determine what determines the readiness to implement innovations related to RES, and in particular, to what extent they are determined by factors related to organizational sustainability (SUS), smartness (SMA) and openness to strategic partnering with customers (SPC).

The survey was conducted between September 2019 and January 2020 interviewing representatives of the management of food companies in Poland randomly selected, which constituted research units. The eligibility criterion for participation in the study was the introduction within the company of any innovation during the last three years. Participants were interviewed using a standardized computer-assisted telephone interviewing (CATI) and in total 157 companies took part in this survey. The characteristics of these companies included in the final sample are illustrated in Table 2.

In the described research process, the behavior and opinions of respondents were analyzed in terms of several key areas for the purposes of the development: orientation towards sustainable development (factors: orientation towards economic goals, orientation towards environmental goals, and orientation towards social goals were analyzed), smartness (factors: orientation towards product innovation, orientation towards marketing innovations, orientation towards technological innovations, orientation towards organizational innovations), strategic partnership with clients (factors analyzed: symmetry of 
benefits, durability of relationships, quality of communication, understanding of needs, frequency of contacts) and the willingness of enterprises to invest in solutions with RES range. All studied variables were assessed on a seven-point scale.

Table 2. Characteristics of the enterprises surveyed $(n=157)$.

\begin{tabular}{ccc}
\hline Enterprise Size: & Frequency & Percentage $\%$ \\
\hline small (10-49 employees) & 61 & 40.56 \\
\hline medium (50-249 employees) & 54 & 34.96 \\
\hline large (over 250 employees) & 42 & 24.48 \\
\hline
\end{tabular}

The IBM SPSS Statistics version 24 software package was used for statistical analyses. Some basic, descriptive statistics are presented in Table 3.

Table 3. Descriptive statistics of the variables examined $(n=157)$.

\begin{tabular}{|c|c|c|c|c|c|c|c|c|}
\hline Variable & Range & Min. & Max. & Average & $\mathbf{M}$ & $\mathbf{D}$ & $\begin{array}{l}\text { Standard } \\
\text { Deviation }\end{array}$ & Variance \\
\hline \multicolumn{9}{|l|}{ Sustainability (SUS) } \\
\hline orientation towards economic goals & 4.00 & 3.00 & 7.00 & 5.81 & 6 & 6 & 0.914 & 0.835 \\
\hline - $\quad$ orientation towards ecological goals & 5.00 & 2.00 & 7.00 & 5.82 & 6 & 6 & 0.990 & 0.981 \\
\hline - $\quad$ orientation towards social goals & 5.00 & 2.00 & 7.00 & 5.46 & 6 & 6 & 1.065 & 1.135 \\
\hline \multicolumn{9}{|l|}{ Smartness (SMA) } \\
\hline - $\quad$ orientation towards product innovation & 5.00 & 2.00 & 7.00 & 5.87 & 6 & 6 & 0.927 & 0.793 \\
\hline - $\quad$ orientation towards marketing innovations & 5.00 & 2.00 & 7.00 & 5.62 & 6 & 6 & 0.944 & 0.891 \\
\hline - $\quad$ orientation towards technological innovations & 4.00 & 3.00 & 7.00 & 5.72 & 6 & 6 & 0.890 & 0.793 \\
\hline - $\quad$ orientation towards organizational innovations & 4.00 & 3.00 & 7.00 & 5.87 & 6 & 6 & 0.934 & 0.873 \\
\hline \multicolumn{9}{|l|}{ Strategic Partnering with Customers (SPC) } \\
\hline - $\quad$ symmetry of benefits & 6.00 & 1.00 & 7.00 & 4.61 & 5 & 5 & 1.339 & 1.792 \\
\hline - durability of relationships & 3.00 & 4.00 & 7.00 & 6.22 & 6 & 6 & 0.730 & 0.533 \\
\hline - $\quad$ quality of communication & 5.00 & 2.00 & 7.00 & 5.25 & 6 & 6 & 1.175 & 1.380 \\
\hline - $\quad$ understanding of needs & 4.00 & 3.00 & 7.00 & 5.88 & 6 & 6 & 0.936 & 0.876 \\
\hline - $\quad$ frequency of contacts & 5.00 & 2.00 & 7.00 & 5.34 & 6 & 6 & 1.096 & 1.201 \\
\hline \multicolumn{9}{|l|}{ RES } \\
\hline RES orientation & 5.00 & 2.00 & 7.00 & 5.70 & 6 & 6 & 1.028 & 1.056 \\
\hline
\end{tabular}

Source: elaborated by the authors based on the results of the study conducted.

In all the surveyed areas, the respondents showed high activity and commitment. In the SUS area, the respondents showed the highest commitment to Orientation towards ecological goals average 5.82 and the lowest in terms of Orientation towards social goals average 5.46. In the SMA area, the highest indications concerned Orientation towards product innovation and Orientation towards organizational innovations, in both cases the average of indications was 5.87, while the lowest was rated for the involvement of respondents in Orientation towards marketing innovations, average to: 5.62. When analyzing the SPC area, it can be noticed that the highest-rated durability of the relationship was 6.22 , and the lowest symmetry of benefits 4.61 . The average willingness of the respondents to invest in RES was 5.7 out of 7 possible points. 


\section{Hypothesis Testing}

In order to verify the existence of the relationship and answer the question whether there is a positive relationship between the level of SPC maturity in the surveyed enterprises and their willingness to invest in RES (H1), a statistical analysis of the relationships between the mentioned variables was carried out. The Cronbach's alpha reliability coefficient for the group of factors related to the maturity level of customer relations (symmetry of benefits, understanding of needs, durability of the relationship, quality of communication, degree of involvement in cooperation, frequency of contacts) was 0.812 . This result shows the internal consistency of the analyzed factors. The analyzes also used the Spearman's rank correlation coefficient; the obtained values are presented in Table 4.

Table 4. Correlation between SPC and RES orientation ( $n=157)$.

\begin{tabular}{|c|c|c|c|}
\hline $\begin{array}{l}\text { Spearman's } \\
\text { Rho }\end{array}$ & & & RES Orientation \\
\hline & \multirow{2}{*}{$\begin{array}{l}\text { Strategic Partnering with } \\
\text { Customers (SPC): }\end{array}$} & $\begin{array}{l}\text { Correlation } \\
\text { Coefficient }\end{array}$ & 0.653 ** \\
\hline & & $\begin{array}{l}\text { Significance } \\
\text { (Two-Sided) }\end{array}$ & 0.000 \\
\hline & \multirow[b]{2}{*}{ symmetry of benefits } & Correlation coefficient & $0.522 * *$ \\
\hline & & $\begin{array}{l}\text { Significance } \\
\text { (two-sided) }\end{array}$ & 0.000 \\
\hline & \multirow[b]{2}{*}{ durability of relationships } & Correlation coefficient & $0.355^{* *}$ \\
\hline & & $\begin{array}{l}\text { Significance } \\
\text { (two-sided) }\end{array}$ & 0.000 \\
\hline & \multirow[b]{2}{*}{ quality of communication } & Correlation coefficient & $0.526^{* *}$ \\
\hline & & $\begin{array}{l}\text { Significance } \\
\text { (two-sided) }\end{array}$ & 0.000 \\
\hline & \multirow[b]{2}{*}{ understanding of needs } & Correlation coefficient & $0.516^{* *}$ \\
\hline & & $\begin{array}{l}\text { Significance } \\
\text { (two-sided) }\end{array}$ & 0.000 \\
\hline & \multirow[b]{2}{*}{ - $\quad$ frequency of contacts } & Correlation coefficient & $0.378^{* *}$ \\
\hline & & $\begin{array}{l}\text { Significance } \\
\text { (two-sided) }\end{array}$ & 0.000 \\
\hline
\end{tabular}

** Correlation significant at 0.01 (two-sided). Source: elaborated by the authors.

The obtained values of the Spearman's rank correlation coefficient prove a positive and statistically significant relationship, the positive nature of the correlation means that the increase in the maturity of customer relations is accompanied by an increase in the propensity of enterprises to invest in RES, the correlation coefficient is $0.653^{* *}$, which proves a moderate dependence. Among the individual factors that make up the maturity of customer relationships, the highest level of Spearman's rank correlation was recorded for the quality of communication, $0.526^{* *}$, and the lowest for the durability of relationships $0.355^{* *}$.

Next, a statistical analysis of the relationship was performed to verify the existence of the cited relationship between the SMA parameters and the maturity of SPC, and thus the validity of the $\mathrm{H} 2$ hypothesis. The Cronbach's alpha reliability coefficient for the group of factors related to the SMA block (focus on product, process, marketing and organizational innovations) was 0.897 , which indicates the internal consistency of the analyzed factors. In the next step of the analysis, Spearman's rank correlation coefficient was used, the obtained values are presented in Table 5. 
Table 5. Correlation between SMA and SPC $(n=157)$.

\begin{tabular}{|c|c|c|c|c|}
\hline $\begin{array}{l}\text { Spearman's } \\
\text { Rho }\end{array}$ & & & & $\begin{array}{c}\text { Strategic Partnering } \\
\text { with Customers (SPC) }\end{array}$ \\
\hline & & \multirow[b]{2}{*}{ Smartness (SMA): } & Correlation coefficient & $0.587^{* *}$ \\
\hline & & & $\begin{array}{l}\text { Significance } \\
\text { (two-sided) }\end{array}$ & 0.000 \\
\hline & \multirow{2}{*}{-} & \multirow{2}{*}{$\begin{array}{l}\text { orientation towards } \\
\text { product innovations }\end{array}$} & Correlation coefficient & $0.486 * *$ \\
\hline & & & $\begin{array}{l}\text { Significance } \\
\text { (two-sided) }\end{array}$ & 0.000 \\
\hline & \multirow{2}{*}{-} & \multirow{2}{*}{$\begin{array}{l}\text { orientation towards } \\
\text { marketing innovations }\end{array}$} & Correlation coefficient & $0.475 * *$ \\
\hline & & & $\begin{array}{l}\text { Significance } \\
\text { (two-sided) }\end{array}$ & 0.000 \\
\hline & \multirow{2}{*}{-} & \multirow{2}{*}{$\begin{array}{l}\text { orientation towards } \\
\text { technological innovations }\end{array}$} & Correlation coefficient & $0.499 * *$ \\
\hline & & & $\begin{array}{l}\text { Significance } \\
\text { (two-sided) }\end{array}$ & 0.000 \\
\hline & \multirow{2}{*}{-} & \multirow{2}{*}{$\begin{array}{l}\text { orientation towards } \\
\text { organizational innovations }\end{array}$} & Correlation coefficient & $0.376 * *$ \\
\hline & & & $\begin{array}{l}\text { Significance } \\
\text { (two-sided) }\end{array}$ & 0.000 \\
\hline
\end{tabular}

The obtained values of the Spearman's rank correlation coefficient prove a positive and statistically significant relationship, the positive nature of the correlation means that the increase in the SMA level is accompanied by an increase in the maturity of SPC, the correlation coefficient is $0.587^{* *}$, which proves a moderate correlation. Among the individual factors that make up the SMA of the surveyed companies, the highest level of Spearman's rank correlation was recorded for orientation towards technological innovations 0.499 **, and the lowest for orientation towards organizational innovations $0.376^{* *}$.

Then, in order to confirm the validity of the adopted hypothesis H3, a statistical analysis of the relationships between SMA and the propensity of enterprises to invest in RES was performed. Here, too, the Spearman's rank correlation coefficient was used, the obtained values are presented in Table 6 .

Table 6. Correlation between SMA and RES orientation $(n=157)$.

\begin{tabular}{|c|c|c|c|c|}
\hline Spearman's Rho & & & & RES Orientation \\
\hline & & \multirow[b]{2}{*}{ Smartness (SMA): } & Correlation coefficient & $0.622 * *$ \\
\hline & & & $\begin{array}{l}\text { Significance } \\
\text { (two-sided) }\end{array}$ & 0.000 \\
\hline & \multirow{2}{*}{-} & \multirow{2}{*}{$\begin{array}{l}\text { orientation towards } \\
\text { product innovations }\end{array}$} & Correlation coefficient & $0.509 * *$ \\
\hline & & & $\begin{array}{l}\text { Significance } \\
\text { (two-sided) }\end{array}$ & 0.000 \\
\hline & \multirow{2}{*}{-} & \multirow{2}{*}{$\begin{array}{l}\text { orientation towards } \\
\text { marketing innovations }\end{array}$} & Correlation coefficient & $0.481 * *$ \\
\hline & & & $\begin{array}{l}\text { Significance } \\
\text { (two-sided) }\end{array}$ & 0.000 \\
\hline & \multirow{2}{*}{-} & \multirow{2}{*}{$\begin{array}{l}\text { orientation towards } \\
\text { technological'innovations }\end{array}$} & Correlation coefficient & $0.470 * *$ \\
\hline & & & $\begin{array}{l}\text { Significance } \\
\text { (two-sided) }\end{array}$ & 0.000 \\
\hline & \multirow{2}{*}{-} & \multirow{2}{*}{$\begin{array}{l}\text { orientation towards } \\
\text { organizational innovations }\end{array}$} & Correlation coefficient & $0.399 * *$ \\
\hline & & & $\begin{array}{l}\text { Significance } \\
\text { (two-sided) }\end{array}$ & 0.000 \\
\hline
\end{tabular}

** Correlation significant at 0.01 (two-sided), Source: elaborated by the authors.

The positive nature of the correlation means that there is a positive and statistically significant relationship and the increase in the SMA level is accompanied by an increase in the RES orientation level, the correlation coefficient is $0.622^{* *}$, which proves a moderate correlation. Among the individual factors that make up the SMA, the highest level of 
Spearman's rank correlation was noted for orientation towards product innovations 0.509 **, and the lowest for orientation towards organizational innovations $0.399^{* *}$.

In order to verify the existence of the relationship mentioned in the $\mathrm{H} 4$ hypothesis between the sustainability (SUS) of the studied enterprises and their maturity in SPC, and thus to confirm its correctness, a statistical analysis was performed. The Spearman's rank correlation coefficient was used in it. Cronbach's alpha reliability coefficient for the SUS factor group (orientation towards economic goals, orientation towards ecological goals, orientation towards social goals) was 0.870 , which indicates the internal consistency of the analyzed factors. The obtained values are presented in Table 7.

Table 7. Correlation between SUS and SPC $(n=157)$.

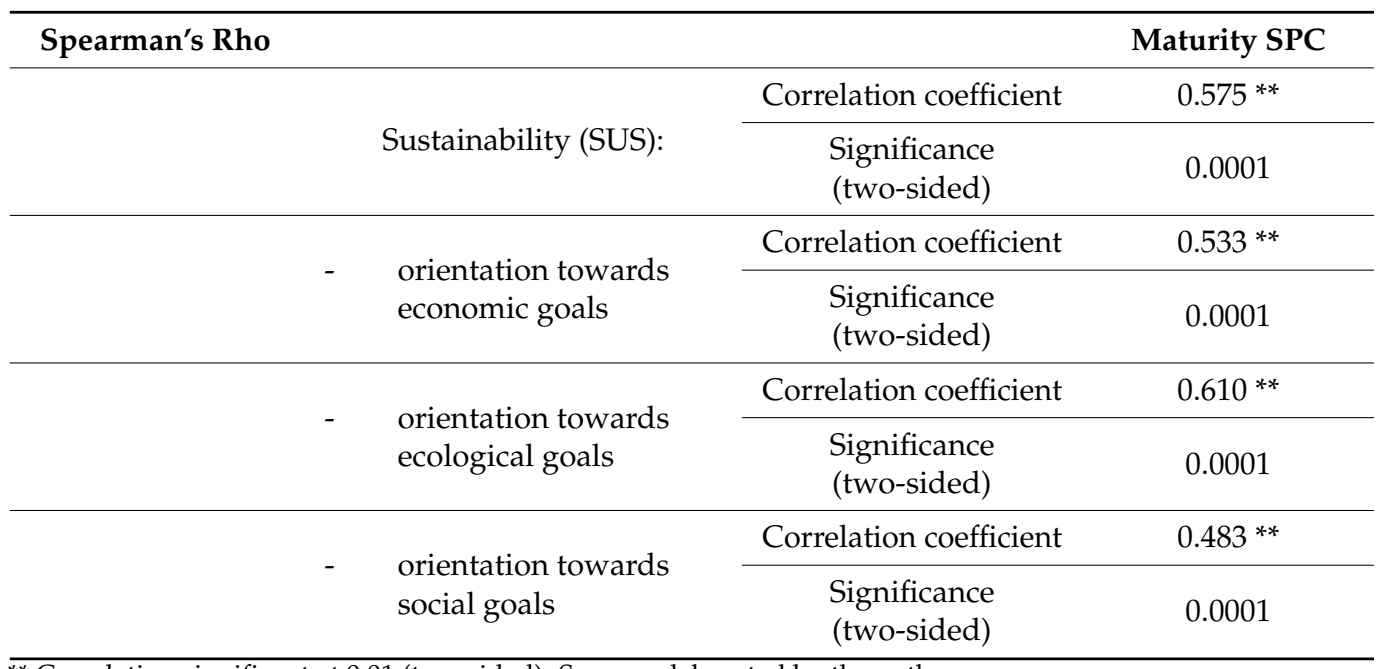

** Correlation significant at 0.01 (two-sided). Source: elaborated by the authors.

The obtained values of the Spearman's rank correlation coefficient prove a positive and statistically significant relationship, the positive nature of the correlation means that an increase in the SUS level is accompanied by an increase in the SPC level, the correlation coefficient is $0.575^{* *}$, which proves a moderate dependence. Among the individual factors that make up the SUS, the highest level of Spearman's rank correlation was recorded for orientation towards ecological goals $0.610^{* *}$, and the lowest for orientation towards social goals $0.483^{* *}$.

In order to verify the last of the $\mathrm{H} 5$ research hypotheses, the relationship between the SUS of the surveyed enterprises and their involvement in the RES was examined. Here, too, as before, the Spearman's rank correlation coefficient was used, the obtained values are presented in Table 8.

The positive nature of the correlation means that there is a positive and statistically significant relationship between the studied variables and the increase in the SUS level is accompanied by an increase in the RES orientation level, the correlation coefficient is $0.727^{* *}$, which proves a moderate relationship. Among the individual factors that make up the SUS, the highest level of Spearman's rank correlation was recorded for orientation towards ecological goals $0.803^{* *}$, and the lowest for orientation towards social goals $0.589^{* *}$. 
Table 8. Correlation between SUS and RES orientation $(n=157)$.

\begin{tabular}{|c|c|c|c|}
\hline Spearman's Rho & & & RES Orientation \\
\hline & \multirow[b]{2}{*}{ Sustainability (SUS): } & Correlation coefficient & $0.727^{* *}$ \\
\hline & & $\begin{array}{l}\text { Significance } \\
\text { (two-sided) }\end{array}$ & 0.0001 \\
\hline & \multirow{2}{*}{$\begin{array}{l}\text { orientation towards } \\
\text { economic goals }\end{array}$} & Correlation coefficient & $0.628^{* *}$ \\
\hline & & $\begin{array}{l}\text { Significance } \\
\text { (two-sided) }\end{array}$ & 0.0001 \\
\hline & \multirow{2}{*}{$\begin{array}{l}\text { orientation towards } \\
\text { ecological goals }\end{array}$} & Correlation coefficient & $0.803^{* *}$ \\
\hline & & $\begin{array}{l}\text { Significance } \\
\text { (two-sided) }\end{array}$ & 0.0001 \\
\hline & \multirow{2}{*}{$\begin{array}{l}\text { - } \quad \text { orientation towards } \\
\text { social goals }\end{array}$} & Correlation coefficient & $0.589 * *$ \\
\hline & & $\begin{array}{l}\text { Significance } \\
\text { (two-sided) }\end{array}$ & 0.0001 \\
\hline
\end{tabular}

\section{Discussion and Conclusions}

The purpose of this study was to identify, justify and explain the determinants of the process of investment in renewable energy sources by the companies studied. The research process was conducted keeping in mind the dependence of these decisions on the strength of the companies' commitment to several strategic issues: sustainability, innovation orientation, as well as the maturity of their partnership with the customer. The results of the analysis of the data collected during the quantitative study conducted indicate a strong correlation between the level of openness of organization IR 4.0 era to RES and (a) their sustainable development orientation, (b) smartness orientation and (c) maturity of strategic partnering with customers. The summary of verification of the hypotheses is demonstrated in Figure 1.

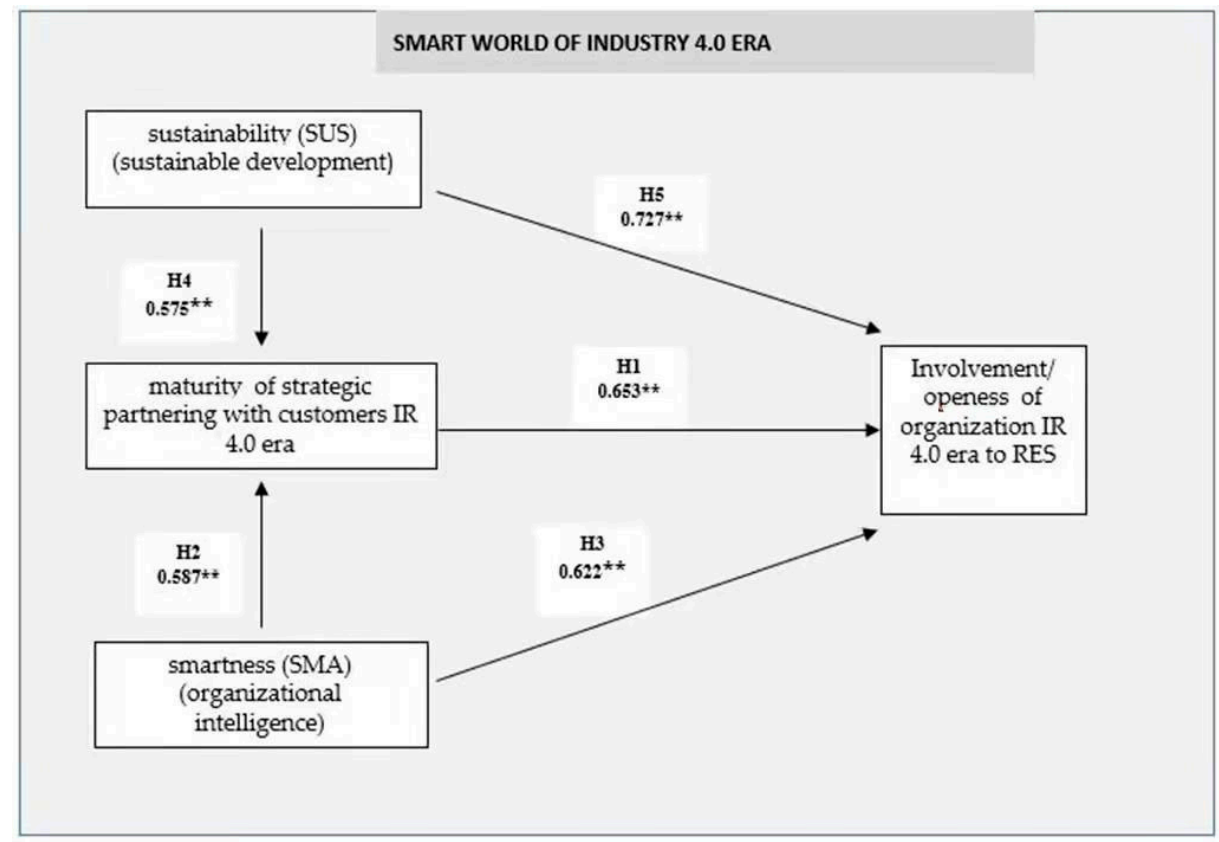

Figure 1. Research model and its verification. $\left({ }^{* *}\right.$ Correlation significant at 0.01 (two-sided). Source: Own study).

In the conditions of the SMART WORLD of Industry 4.0 era, investments in renewable energy sources are an important direction for sustainable development. The actions taken by 
enterprises in this regard should be stimulated by the demand side. The results of our pilot study conducted for companies in the food sector showed that an increase in companies' openness to RES investments is associated with a higher level of strategic partnership with customers (as verified by H1). Consumers' attitude towards RES investment determines their propensity to choose brands that invest in RES, which in turn makes companies more willing to invest in RES to influence consumer choices. This fact in turn makes enterprises more and more willing to invest in RES in order to attract customers and then influence their market choices.

In the context of the considerations carried out, it is necessary to agree with the conclusions of research conducted around the world [18,71,72,107,113]. Interaction with the customer is important for the realization of businesses, and consumer choices strongly determine decisions, especially in the nature of innovations implemented $[9,114]$ as well as the forms of sustainability actions taken [18,115]. Companies that collaborate with consumers in the process of creating innovative solutions are more open to sustainability activities $[9,16,70,72]$. The results of our study confirm that mature partnership with customers (SPC) is for many companies, a premise for successful implementation of innovative solutions [98], it is also a catalyst for openness to RES. The determinants of activity in this regard are their SMA and SUS. These factors shape the openness of Industry 4.0 era organizations to RES in two ways. The first, direct, by virtue of its environmental-social (as verified by $\mathrm{H} 5$ ) and economic-technological (as verified by H3) nature. The second, indirect, through conscious decisions and purchasing choices of customers who choose products of innovative companies (SMA) (which is verified by H2), and at the same time socially responsible companies (SUS) (which is verified by H4), thus including those investing in RES.

The elements evaluated in the study characterizing the strategic partnership with the customer are symmetry of benefits, the durability of relationships, quality of communication, understanding of needs and frequency of contacts. The highest correlation coefficient $0.526^{* *}$ occurred for the quality of communication, a slightly lower $0.522{ }^{* *}$ was recorded for the symmetry of benefits. The innovativeness of an organization is therefore strongly related to having efficient channels of communication with the client. Thanks to them, partners efficiently inform each other about their needs, activities and achievements, thanks to which the knowledge of each party is constantly expanded $[98,116]$.

Despite the high propensity to implement RES solutions, there are still barriers that stop companies (even innovative, customer-focused, and sustainable ones) from implementing such solutions. One of the key ones may be the high cost of implementation. Our study points out that although the cost of implementing investments in renewable energy sources is unfortunately still high, it can bring a number of benefits to the implementers, not only the purely tangible ones (e.g., lower energy costs, energy independence), but also the intangible ones, the main ones being the positive perception of the company by customers, image of the company as socially responsible, complying with the guidelines/objectives of sustainable development, friendly to the environment and future generations, etc. It is often also a greater respect and recognition for those who do not think only about themselves but also about others. It also means more and more opportunities for financial support from various programs and funds for those organizations which are "on track" with the goals of sustainable development, e.g., 2030. The ability of companies to build lasting relationships with customers, good quality of communication, understanding of needs and high frequency of contacts with customers are helpful in achieving such effects. When such conditions are created, customers are more willing to share knowledge. This is extremely important nowadays, since the innovation of organizations is strongly related to the possession and constant expansion of knowledge [98,116], in turn, customers are willing to share knowledge if they are aware that it provides benefits to both parties of the exchange. Our study highlights that consumers are willing to share responsibility for environmental degradation [18] and expect the same from entrepreneurs, as partnerships 
should be two-way. In this way, a new quality is created a socially responsible partnership, which lays the foundation for the growing openness of enterprises to involvement in RES.

The article is an original study that, based on an original questionnaire, shows the relationships between partnership with customers, organizational smartness, sustainability of food enterprises and their openness to RES investments. Identification of these relationships can help enterprises to formulate directions for their improvement on the way to effective functioning in the SMART WORLD environment. The diagnosed direction, scope and importance of partnerships with customers of enterprises operating in the food sector, justifies the need to undertake the analyzed research problem, and at the same time encourages its further recognition, especially in order to formulate valuable recommendations for business practice, also in other branches, industries, and even sectors. Socially responsible partnership, not only with customers, has increasing development prospects. Its concept as an operational element for the practical implementation of the goals of global sustainable development seems to be invaluable on more and more levels.

\section{Contribution to the Theory and Limitations}

The trend of increasing awareness of sustainability issues among consumers is slowly starting to translate into consumer behavior. This is important because the decisions and strategies of producers depend on what consumers expect. This includes decisions regarding investments in renewable energy sources. The cited research shows that aspects such as customer requirements or the analysis of the elements of the marketing mix are widely considered. The same is true of aspects such as involvement in the RES, importance, financing, and the technologies used in the RES. However, in the studies to date, not all issues have been addressed. These areas were identified in our study as research gaps. Thus, in the study, we answered questions about the relationship between smartness, sustainability, maturity and the openness of food sector companies regarding investments in RES. The proposed model addresses the research gap in identifying the relationship between organizational smartness (SMA), sustainability (SUS), maturity of strategic partnering with customers (SPC), and openness of food companies to RES investment (RES). It gives a clear indication of the direction of the interactions of the factors (and also blocks of factors) under study.

The food sector is currently innovative, characterized by high modernity and mechanization. Strong competition forces to care about consumer satisfaction, building product brands and meeting the needs of sustainable development. The need to build and maintain a competitive position means that companies in the food sector should pay more and more attention not only to economic issues, the constant search for innovation and building their own strong brands, but also make sure that their activities are environmentally friendly, assessed positively not only by customers, but also by the broader social, economic and even natural environment.

Therefore, enterprises should not only engage more intensively in SDG-related activities, including RES commitments, but also promote their ideas and inform their audiences about their investments in this field. This will support the environment, improve their image, and at the same time offer them a chance to increase the number of loyal customers.

The surveyed companies, as their level of customer partnership maturity increases, declare an increasing willingness to invest in RES. This relationship results from the fact that consumers are increasingly interested in environmental protection. They more and more often carry out activities in this area on their own, in their own households, but also more and more openly manifest their support and favoring of enterprises, especially manufacturers, who are ready to invest in CSR and RES. Businesses perceiving this trend, as if in response to it, are more and more willing to undertake such actions.

From a managerial perspective, an important conclusion emerges from our study. Managers need to realize that partnering with customers costs money, requiring not only financial resources but also the time and effort of many people. Partnership projects can consume more than other projects, different resources because of the additional cost 
and time to manage the complexity of such a joint initiative. Partnerships with clients, therefore, need to be adequately prepared. Actions taken in this regard should be preceded by appropriate research, e.g., into consumer opinions, changes in their needs, tastes or interests. Such support will definitely increase the accuracy of decisions and investments.

Our study highlights that it is important for managers to have realistic expectations about the outcomes of partnerships with customers and knowledge about the benefits they can derive from such partnerships and how they can exploit them. Unfortunately, there is still quite limited knowledge among entrepreneurs about the mechanisms and forms of effectively establishing, maintaining, developing, or leveraging inter-organizational partnerships. Managers often act intuitively, making classic mistakes, or fail to see the real opportunities inherent in this type of relationship. Among other things, they need a better understanding of how values are shared between partners before they engage in innovation development partnerships. Trainings in, e.g., relationship capital management, negotiation, business communication, customer relationship building, environmental management etc. are a good support for practitioners in this area.

Our survey signals that investments in RES are, on the one hand, an important factor in building a competitive advantage and a positive image of the company on the market, but also, on the other hand, an important added value for the customer. Companies should learn to clearly and decisively make this clear to customers. Each company should find its own way to communicate to its partners, including customers, the forms and reasons of its involvement in the realization of investments connected with sustainable development, which are also investments in RES. Partners should understand that this type of activity is an additional, above-average value given to them by the company, which not all manufacturers can afford to offer yet. It is still a distinctive feature of the best ones.

It seems that the results gathered in the course of the conducted analyses are inspiring and worth further, more thorough research. Their value results mainly from combining in one, unique bundle such core competencies of contemporary organisations as innovativeness, sustainable development orientation, customer orientation, as well as correlating them with companies' openness to investing in RES. They have created a cause for attempts to identify other bundles of determinants of companies' engagement in RES, to undertake research in this field in other industries, sectors, and even industries, as well as to activate the search for methods and tools that support the promotion of RES engagement, not only among the producers, but also among the customers.

With both the conclusions presented and the focus of future research, we hope to contribute to a more contextual understanding of the phenomena related to the importance of RES investments for achieving the key objectives in the companies in the sector studied.

We believe that the conclusions of the study contribute to a clearer picture of reality, as they show the relationships between the examined areas through the analysis of the companies' declarations. Further research should focus on preference analysis and consumer awareness. Investments in RES have costs, so consumers should learn to contribute to these costs, e.g., by paying a higher price for an offer, if they are aware of its contribution to sustainability.

We believe that our findings provide useful managerial implications because without knowledge of the factors that support value creation in today's sustainable enterprise, they will not succeed in the SMART WORLD era. Although this study covered some novel issues, it still has some limitations that can be improved in future research.

Other perceived limitations of the research are the fact that the survey covered enterprises that have implemented any innovation in recent years, which means that there is no reference sample. In food sector enterprises, the partnership with customers is almost mandatory in order to implement innovation. The second important issue is the fact that only the demand side was researched, which could be supplemented by studies of consumers' attitudes. Additional analysis from the point of view of enterprise employees also seems reasonable. 
Finally, a certain limitation of this study is its cross-sectional and rather general nature. Consequently, the study does not indicate in detail what new product developers have learned from their customer partners. Thus, longitudinal studies will be needed in the future to determine how the actual value of the customer partnership translates into real investment in RES in the future.

Author Contributions: Conceptual approach: A.A., K.L.-K., P.P. and A.W.; data curation: K.L.-K.; software, K.L.-K.; calculations: K.L.-K. modeling: A.A., K.L.-K., P.P. and A.W.; writing of original draft: A.A., K.L.-K., P.P. and A.W.; review and editing: A.A., K.L.-K. and A.W. All authors have read and agreed to the published version of the manuscript.

Funding: This research received no external funding.

Institutional Review Board Statement: Not applicable.

Informed Consent Statement: Not applicable.

Data Availability Statement: The data presented in this study are available on request from the corresponding author.

Acknowledgments: The concept of this paper was discussed during the III Congress of Modern Management in Poland. The authors thank the participants for a fruitful discussion.

Conflicts of Interest: The authors declare no conflict of interest.

$\begin{array}{ll}\text { Abbreviations } \\ \text { IR 4.0 } & \text { Industry 4.0 } \\ \text { RES } & \text { renewable energy sources } \\ \text { CSR } & \text { Corporate Social Responsibility } \\ \text { SDG } & \text { Sustainable Development Goals } \\ \text { SED } & \text { Sustainable Energy Development } \\ \text { EU } & \text { European Union } \\ \text { GW } & \text { giga watts } \\ \text { MW } & \text { mega watts } \\ \text { R\&D } & \text { research and development } \\ \text { SPC } & \text { strategic partnering with customers } \\ \text { SMA } & \text { smartness } \\ \text { SUS } & \text { sustainability }\end{array}$

\section{References}

1. Adamik, A.; Sikora-Fernandez, D. Smart organizations as a source of competitiveness and sustainable development in the age of industry 4.0: Integration of micro and macro perspective. Energies 2021, 14, 1572. [CrossRef]

2. Adamik, A. SMEs on the Way to the Smart World of Industry 4.0. In Eurasian Business Perspectives; Springer: Cham, Switzerland, 2020; pp. 139-156. [CrossRef]

3. Iapichino, A.; De Rosa, A.; Liberace, P. Smart organizations, new skills, and smart working to manage companies' digital transformation. In Digitized Labor: The Impact of the Internet on Employment; Springer International Publishing: Cham, Switzerland, 2018; pp. 215-227. ISBN 9783319784205.

4. Berawi, M.A. Utilizing big data in industry 4.0: Managing competitive advantages and business ethics. Int. J. Technol. 2018, 9 , 430-433. [CrossRef]

5. Adamik, A. Change and Relational Strategies: Through an Organizational Intelligence Lens. In Organizational Change and Relational Resources; Routledge: Oxfordshire, UK, 2021; pp. 47-77. [CrossRef]

6. Ghadimi, P.; Wang, C.; Lim, M.K.; Heavey, C. Intelligent sustainable supplier selection using multi-agent technology: Theory and application for Industry 4.0 supply chains. Comput. Ind. Eng. 2019, 127, 588-600. [CrossRef]

7. Adamik, A. Anna Adamik Partnerstwo Strategiczne a Konkurencyjność Przedsiębiorstw. 2016. Available online: https://www. infona.pl/resource/bwmeta1.element.baztech-563a0155-d1b4-4026-b37f-fc9ed1403b91 (accessed on 14 November 2021).

8. Ślusarczyk, B. Industry 4.0-Are we ready? Polish J. Manag. Stud. 2018, 17, 232-248. [CrossRef]

9. Liczmańska-Kopcewicz, K.; Glabiszewski, W.; Grego-Planer, D.; Zastempowski, M. The role of the buyer's knowledge in developing product innovations in the FMCG sector. In Proceedings of the 31st International Business Information Management Association Conference, IBIMA 2018: Innovation Management and Education Excellence through Vision 2020, Milan, Italy, 25-26 April 2018; pp. 3682-3692. Available online: https://www.elibrary.ru/item.asp?id=38654158 (accessed on 4 November 2021). 
10. Liczmańska-Kopcewicz, K.; Zastempowski, M. Significance of Proactive Customer Orientation in Creating Product Innovations in Cooperation with the Consumer. In Contemporary Challenges in Cooperation and Coopetition in the Age of Industry 4.0; Springer: Cham, Switzerland, 2020; pp. 331-342. [CrossRef]

11. Grębosz-Krawczyk, M.; Zakrzewska-Bielawska, A.; Glinka, B.; Glińska-Neweś, A. Why do consumers choose photovoltaic panels? Identification of the factors influencing consumers' choice behavior regarding photovoltaic panel installations. Energies 2021, 14, 2674. [CrossRef]

12. Atuahene-Gima, K. Involving organizational buyers in new product development. Ind. Mark. Manag. 1995, 24, 215-226. [CrossRef]

13. Menguc, B.; Auh, S.; Yannopoulos, P. Customer and Supplier Involvement in Design: The Moderating Role of Incremental and Radical Innovation Capability. J. Prod. Innov. Manag. 2014, 31, 313-328. [CrossRef]

14. Glińska-Neweś, A.; Brzustewicz, P.; Escher, I.; Fomina, Y.; Józefowicz, B.; Katunina, I.; Petrykowska, J.; Szostek, D. Company Involvement in Sustainable Development-Proposition of a Theoretical Framework. In Contemporary Challenges in Cooperation and Coopetition in the Age of Industry 4.0; Springer: Cham, Switzerland, 2019; pp. 439-451. [CrossRef]

15. Beier, G.; Niehoff, S.; Ziems, T.; Xue, B. Sustainability aspects of a digitalized industry-A comparative study from China and Germany. Int. J. Precis. Eng. Manuf.-Green Technol. 2017, 4, 227-234. [CrossRef]

16. Liczmańska-Kopcewicz, K.; Pypłacz, P.; Wiśniewska, A. Resonance of Investments in Renewable Energy Sources in Industrial Enterprises in the Food Industry. Energies 2020, 13, 4285. [CrossRef]

17. Panwar, N.L.; Siva Reddy, V.; Ranjan, K.R.; Seepana, M.M.; Totlani, P. Sustainable development with renewable energy resources: A review. World Rev. Sci., Technol. Sustain. Dev. 2013, 10, 163-184. [CrossRef]

18. Mansoor, M.; Paul, J. Consumers' choice behavior: An interactive effect of expected eudaimonic well-being and green altruism. Bus. Strateg. Environ. 2021, 1-16. [CrossRef]

19. Cyfert, S.; Glabiszewski, W.; Zastempowski, M. Impact of management tools supporting industry 4.0 on the importance of csr during covid-19. generation z. Energies 2021, 14, 1642. [CrossRef]

20. Marczewska, M. The Role of Competitors and Customers in the Development of Environmentally Sound Technologies. J. Entrep. Manag. Innov. 2014, 10, 39-61. [CrossRef]

21. Chu, S.; Majumdar, A. Opportunities and challenges for a sustainable energy future. Nature 2012, 488, 294-303. [CrossRef] [PubMed]

22. Chu, S.; Cui, Y.; Liu, N. The path towards sustainable energy. Nat. Mater. 2016, 16, 16-22. [CrossRef]

23. Assefa, G.; Frostell, B. Social sustainability and social acceptance in technology assessment: A case study of energy technologies. Technol. Soc. 2007, 29, 63-78. [CrossRef]

24. Buszko, M.; Ciechan-Kujawa, M. Influence of Deregulation on Sustainable Development of Sector of Professional Financial and Accounting Services in Poland: An Empirical Study. In Finance and Sustainability; Springer: Cham, Switzerland, 2020; pp. 277-289. [CrossRef]

25. Choi, S.; Ng, A. Environmental and Economic Dimensions of Sustainability and Price Effects on Consumer Responses. J. Bus. Ethics 2011, 104, 269-282. [CrossRef]

26. Liu, J.; Scanlon, B.R.; Zhuang, J.; Varis, O. Food-Energy-Water Nexus for Multi-scale Sustainable Development. Resour. Conserv. Recycl. 2020, 154, 104565. [CrossRef]

27. Ford, S.; Despeisse, M. Additive manufacturing and sustainability: An exploratory study of the advantages and challenges. J. Clean. Prod. 2016, 137, 1573-1587. [CrossRef]

28. Marczewska, M.; Kostrzewski, M. Sustainable Business Models: A Bibliometric Performance Analysis. Energies 2020, 13, 6062. [CrossRef]

29. Chwiłkowska-Kubala, A.; Cyfert, S.; Malewska, K.; Mierzejewska, K.; Szumowski, W. The Relationships among Social, Environmental, Economic CSR Practices and Digitalization in Polish Energy Companies. Energies 2021, 14, 7666. [CrossRef]

30. Liczmańska-Kopcewicz, K.; Mizera, K.; Pypłacz, P. Corporate Social Responsibility and Sustainable Development for Creating Value for FMCG Sector Enterprises. Sustainability 2019, 11, 5808. [CrossRef]

31. Bansal, P. Evolving sustainably: A longitudinal study of corporate sustainable development. Strateg. Manag. J. 2005, 26, 197-218. [CrossRef]

32. Hąbek, P.; Lechowicz, P. Assessment of sustainable production practices. The case of company from metal industry. Multidiscip. Asp. Prod. Eng. 2019, 2, 447-456. [CrossRef]

33. Wittmayer, J.M.; Avelino, F.; Pel, B.; Campos, I. Contributing to sustainable and just energy systems? The mainstreaming of renewable energy prosumerism within and across institutional logics. Energy Policy 2021, 149, 112053. [CrossRef]

34. Bilgen, S.; Kaygusuz, K.; Sari, A. Renewable energy for a clean and sustainable future. Energy Sources 2004, 26, 1119-1129. [CrossRef]

35. Panwar, N.L.; Kaushik, S.C.; Kothari, S. Role of renewable energy sources in environmental protection: A review. Renew. Sustain. Energy Rev. 2011, 15, 1513-1524. [CrossRef]

36. Kuceba, R.; Chmielarz, G.; Soltysiak, M. Vital factors stimulating development and competitiveness of design and construction enterprises of photovoltaic farms. Energies 2021, 14, 3399. [CrossRef]

37. Smirnova, E.; Kot, S.; Kolpak, E.; Shestak, V. Governmental support and renewable energy production: A cross-country review. Energy 2021, 230, 120903. [CrossRef] 
38. Magda, R.; Meyer, N.; Bozsik, N. The role of renewable energies in the new EU member states. J. East. Eur. Cent. Asian Res. 2021, 8, 18. [CrossRef]

39. Mehmood, U. Contribution of renewable energy towards environmental quality: The role of education to achieve sustainable development goals in G11 countries. Renew. Energy 2021, 178, 600-607. [CrossRef]

40. Yumashev, A.; Ślusarczyk, B.; Kondrashev, S.; Mikhaylov, A. Global indicators of sustainable development: Evaluation of the influence of the human development index on consumption and quality of energy. Energies 2020, 13, 2768. [CrossRef]

41. Gadeikienè, A.; Dovalienè, A.; Grase, A.; Banytė, J. Sustainable consumption behaviour spill-over from workplace to private life: Conceptual framework. Polish J. Manag. Stud. 2019, 19, 142-154. [CrossRef]

42. Jacobson, M.Z.; Delucchi, M.A. Providing all global energy with wind, water, and solar power, Part I: Technologies, energy resources, quantities and areas of infrastructure, and materials. Energy Policy 2011, 39, 1154-1169. [CrossRef]

43. Jurasz, J.; Canales, F.A.; Kies, A.; Guezgouz, M.; Beluco, A. A review on the complementarity of renewable energy sources: Concept, metrics, application and future research directions. Sol. Energy 2020, 195, 703-724. [CrossRef]

44. Marinescu, N. Changes in renewable energy policy and their implications: The case of Romanian producers. Energies 2020, 13, 6493. [CrossRef]

45. Krepl, V.; Shaheen, H.I.; Fandi, G.; Smutka, L.; Muller, Z.; Tlustý, J.; Husein, T.; Ghanem, S. The role of renewable energies in the sustainable development of post-crisis electrical power sectors reconstruction. Energies 2020, 13, 6326. [CrossRef]

46. Qazi, A.; Hussain, F.; Rahim, N.; Hardaker, G. W Kierunku Zrównoważonej Energii: Systematyczny Przegląd Odnawialnych Źródeł Energii, Technologii i Opinii Publicznej, IEEE. 2019. Available online: https:/ / ieeexplore.ieee.org/abstract/document/87 21134/ (accessed on 17 July 2021).

47. Głośniewska, A. Coraz Więcej Zielonej Energii z Małych Instalacji OZE—Kolejny Raport Prezesa URE. 2020. Available online: https://www.ure.gov.pl/pl/urzad/informacje-ogolne/aktualnosci/8830,Coraz-wiecej-zielonej-energii-z-malych-instalacjiOZE-kolejny-raport-Prezesa-URE.html (accessed on 5 November 2021).

48. Mahrinasari, M.S.; Haseeb, M.; Ammar, J. Meiryani Is trade liberalization a hazard to sustainable environment? Fresh insight from asean countries. Polish J. Manag. Stud. 2019, 19, 249-259. [CrossRef]

49. Wasilczuk, J. Advantageous competence of owner/managers to grow the firm in Poland: Empirical evidence. J. Small Bus. Manag. 2000, 38, 88-94.

50. Czakon, W. The building blocks of a relational capability-Evidence from the banking industry. Int. J. Entrep. Ventur. 2009, 1, 131-146. [CrossRef]

51. Jahn, S. Konsumentenwert. Konzeptualisierung und Analyse der Wirkungen auf Zufriedenheit und Loyalität am Beispiel eines Festivals; Springer Gabler: Wiesbaden, Germany, 2013; ISBN 978-3-658-02735-3.

52. Kotzab, H.; Teller, C. Value-adding partnerships and co-opetition models in the grocery industry. Int. J. Phys. Distrib. Logist. Manag. 2003, 33, 268-281. [CrossRef]

53. Panwar, N.L.; Kothari, S.; Kaushik, S.C. Cost-benefit and systems analysis of passively ventilated solar greenhouses for food production in arid and semi-arid regions. Environ. Syst. Decis. 2014, 34, 160-167. [CrossRef]

54. Bigliardi, B.; Dormio, A.; Galati, F. Successful co-opetition strategy: Evidence from an Italian consortium. Int. J. Bus. Manag. Soc. Sci. 2011, 2, 1-8.

55. Baumann, J.P.; Gulati, R.; Alter, C.; Hage, J. Organizations Working Together. Adm. Sci. Q. 1994, 39, 355. [CrossRef]

56. Deering, A.; Murphy, A. The Partnering Imperative: Making Business Partnerships Work. 2003. Available online: www. wileyeurope.com (accessed on 3 November 2021).

57. Darby, M. Alliance Brand: Fulfilling the Promise of Partnering. 2006. Available online: https://books.google.com/books?hl= pl\&lr=\&id=S3TUjTL9ZWAC\&oi=fnd\&pg=PP2\&dq=Darby, +Alliance+Brand:+Fulfilling +the+Promise+of+Partnering,+ John + \&ots=3oihDHT86S\&sig=tzTqtcK3aMsagmd9oq7vlTBKawE (accessed on 3 November 2021).

58. Adamik, A. Creating a Competitive Advantage in the Age of Industry 4.0. Probl. Zarz. 2019, 17, 13-31. [CrossRef]

59. Porter, M.E. Creating and Sustaining Superior Performance. Compet. Advant. 1985, 167, 1-30. Available online: https://www. academia.edu/download/43857184/Competitive_Advantage-_creative_and_sustaining.pdf (accessed on 7 November 2021).

60. Bagdonienè, D.; Simanavičienè, A.; Aimuntas, G. System of Balanced Sustainable Development Indicators: The Case of Sc Teo. Manag. Theory Stud. Rural Bus. Infrastruct. Dev. 2011, 1, 16-25.

61. Doz, Y.; Hamel, G. Alliance Advantage: The Art of Creating Value through Partnering; Harvard Business School Press: Boston, MA, USA, 1998. Available online: https:/ / books.google.com/books?hl=en\&lr=\&id=tp7Ct-Df5nkC\&oi=fnd\&pg=PR9\&dq=Doz,+Y. + and + Hamel, + G. $+(1998)+$ Alliance + Advantage:+The+Art+of+Creating +Value+through + Partnering\&ots=y1Jd1nmtWp\&sig $=$ xfXzr8crvsTfkkWNglu-9u_gnEs (accessed on 14 November 2021).

62. Dyer, J.H.; Hatch, N.W. Relation-specific capabilities and barriers to knowledge transfers: Creating advantage through network relationships. Strateg. Manag. J. 2006, 27, 701-719. [CrossRef]

63. Kindström, D.; Kowalkowski, C.; Nordin, F. Visualizing the value of service-based offerings: Empirical findings from the manufacturing industry. J. Bus. Ind. Mark. 2012, 27, 538-546. [CrossRef]

64. Amara, N.; Landry, R. Sources of information as determinants of novelty of innovation in manufacturing firms: Evidence from the 1999 statistics Canada innovation survey. Technovation 2005, 25, 245-259. [CrossRef]

65. Tether, B.S. Who cooperates for innovation, and why an empirical analysis. Res. Policy 2002, 31, 947-967. [CrossRef] 
66. Joshi, A.W.; Sharma, S. Customer knowledge development: Antecedents and impact on new product performance. J. Mark. 2004, 68, 47-59. [CrossRef]

67. Hsu, Y. Cocreation experiences: A strategic approach to product innovation and design. Int. J. Organ. Innov. 2017, 10, 106-126.

68. Ritala, P.; Huizingh, E. Business and network models for innovation: Strategic logic and the role of network position. Int. J. Technol. Manag. 2014, 66, 109-119. [CrossRef]

69. Adamik, A.; Nowicki, M.; Szymańska, K. Openness to co-creation as a method of reducing the complexity of the environment and dynamizing companies' competitive advantages. Manag. Mark. 2018, 13, 880-896. [CrossRef]

70. Abdel-Basset, M.; Gamal, A.; Chakrabortty, R.K.; Ryan, M.J. Evaluation approach for sustainable renewable energy systems under uncertain environment: A case study. Renew. Energy 2021, 168, 1073-1095. [CrossRef]

71. Esa, E.; Zahari, A.R.; Nawang, D. Corporate Sustainability Reporting, Ownership Structure and Brand Equity. Glob. Bus. Manag. Res. 2018, 10, 120-129.

72. Gilal, F.G.; Paul, J.; Gilal, N.G.; Gilal, R.G. Strategic CSR-brand fit and customers' brand passion: Theoretical extension and analysis. Psychol. Mark. 2021, 38, 759-773. [CrossRef]

73. Berglund, C.; Matti, S. Citizen and consumer: The dual role of individuals in environmental policy. Env. Polit. 2006, 15, 550-571. [CrossRef]

74. Dick, A.S.; Basu, K. Customer loyalty: Toward an integrated conceptual framework. J. Acad. Mark. Sci. 1994, 22, 99-113. [CrossRef]

75. Kumar, V.; Shah, D. Building and sustaining profitable customer loyalty for the 21st century. J. Retail. 2004, 80, 317-329. [CrossRef]

76. Uncles, M.D.; Dowling, G.R.; Hammond, K. Customer loyalty and customer loyalty programs. J. Consum. Mark. 2003, 20, 294-316. [CrossRef]

77. Ghadeer, A.-E. Analyzing the Antecedents of Customer Loyalty. Br. J. Mark. Stud. 2015, 3, 34-48.

78. Leckie, C.; Nyadzayo, M.W.; Johnson, L.W. Antecedents of consumer brand engagement and brand loyalty. J. Mark. Manag. 2016, 32, 558-578. [CrossRef]

79. Perugini, M.; Bagozzi, R.P. The role of desires and anticipated emotions in goal-directed behaviours: Broadening and deepening the theory of planned behaviour. Br. J. Soc. Psychol. 2001, 40, 79-98. [CrossRef]

80. Trischler, J.; Johnson, M.; Kristensson, P. A service ecosystem perspective on the diffusion of sustainability-oriented user innovations. J. Bus. Res. 2020, 116, 552-560. [CrossRef]

81. Biswas, A.; Roy, M. Green products: An exploratory study on the consumer behaviour in emerging economies of the East. $J$. Clean. Prod. 2015, 87, 463-468. [CrossRef]

82. Atuahene-Gima, K. An Exploratory Analysis of the Impact of Market Orientation on New Product Performance. J. Prod. Innov. Manag. 2003, 12, 275-293. [CrossRef]

83. Füller, J.; Bartl, M.; Ernst, H.; Mühlbacher, H. Community based innovation-A method to utilize the innovative potential of online communities. In Proceedings of the Hawaii International Conference on System Sciences, Big Island, HI, USA, 5-8 January 2004; Volume 37, pp. 3065-3074. [CrossRef]

84. Cho, H.J.; Pucik, V. Relationship between innovativeness, quality, growth, profitability, and market value. Strateg. Manag. J. 2005, 26, 555-575. [CrossRef]

85. Rajapathirana, R.P.J.; Hui, Y. Relationship between innovation capability, innovation type, and firm performance. J. Innov. Knowl. 2018, 3, 44-55. [CrossRef]

86. Dziurski, P.; Mierzejewska, W.; Sopińska, A.; Wachowiak, P. Managing Innovation in the Context of the Bright and Dark Sides of Innovation-Conclusions from the Study. In Critical Perspectives on Innovation Management; Routledge: New York, NY, USA, 2021; pp. 137-153. [CrossRef]

87. Dyduch, W.; Chudziński, P.; Cyfert, S.; Zastempowski, M. Dynamic capabilities, value creation and value capture: Evidence from SMEs under Covid-19 lockdown in Poland. PLoS ONE 2021, 16, e0252423. [CrossRef]

88. Rubera, G.; Kirca, A.H. Firm innovativeness and its performance outcomes: A meta-analytic review and theoretical integration. $J$ Mark. 2012, 76, 130-147. [CrossRef]

89. Danneels, E.; Kleinschmidtb, E.J. Product innovativeness from the firm's perspective: Its dimensions and their relation with project selection and performance. J. Prod. Innov. Manag. 2001, 18, 357-373. [CrossRef]

90. Hughes, M.; Hughes, P.; Hodgkinson, I.; Chang, Y.Y.; Chang, C.Y. Knowledge-based theory, entrepreneurial orientation, stakeholder engagement, and firm performance. Strateg. Entrep. J. 2021, 1-33. [CrossRef]

91. Vanhaverbeke, W.; Roijakkers, N.; Lorenz, A.; Chesbrough, H. The importance of connecting open innovation to strategy. In Strategy and Communication for Innovation: Integrative Perspectives on Innovation in the Digital Economy; Springer International Publishing: Cham, Switzerland, 2017; pp. 3-15; ISBN 9783319495422. [CrossRef]

92. Klimas, P.; Czakon, W. Species in the wild: A typology of innovation ecosystems. Rev. Manag. Sci. 2021, 1-34. [CrossRef]

93. Sacchi, G.; Stefani, G.; Romano, D.; Nocella, G. Consumer renaissance in Alternative Agri-Food Networks between collective action and co-production. Sustain. Prod. Consum. 2021, 29, 311-327. [CrossRef]

94. Kunz, W.; Schmitt, B.; Meyer, A. How does perceived firm innovativeness affect the consumer? J. Bus. Res. 2011, 64, 816-822. [CrossRef]

95. Im, S.; Workman, J.P. Market Orientation, Creativity, and New Product Performance in High-Technology Firms. J. Mark. 2004, 68, 114-132. [CrossRef] 
96. Baum, J.A.; Silverman, B.S. Picking winners or building them? Alliance, intellectual, and human capital as selection criteria in venture financing and performance of biotechnology startups. J. Bus. Ventur. 2004, 19, 411-436. [CrossRef]

97. Zakrzewska-Bielawska, A. Strategie Rozwoju Przedsiębiorstw; Nowe Spojrzenie: Warsaw, Poland, 2018.

98. Su, Y.S.; Tsang, E.W.K.; Peng, M.W. How do internal capabilities and external partnerships affect innovativeness? Asia Pac. J. Manag. 2009, 26, 309-331. [CrossRef]

99. West, J.; Bogers, M. Leveraging external sources of innovation: A review of research on open innovation. J. Prod. Innov. Manag. 2014, 31, 814-831. [CrossRef]

100. Crossan, M.M.; Apaydin, M. A multi-dimensional framework of organizational innovation: A systematic review of the literature. J. Manag. Stud. 2010, 47, 1154-1191. [CrossRef]

101. Medrano, N.; Olarte-Pascual, C. The effects of the crisis on marketing innovation: An application for Spain. J. Bus. Ind. Mark. 2016, 31, 404-417. [CrossRef]

102. Zastempowski, M.; Cyfert, S. Social responsibility of SMEs from the perspective of their innovativeness: Evidence from Poland. J. Clean. Prod. 2021, 317, 128400. [CrossRef]

103. Glavič, P.; Lukman, R. Review of sustainability terms and their definitions. J. Clean. Prod. 2007, 15, 1875-1885. [CrossRef]

104. Kamble, S.S.; Gunasekaran, A.; Gawankar, S.A. Sustainable Industry 4.0 framework: A systematic literature review identifying the current trends and future perspectives. Process. Saf. Environ. Prot. 2018, 117, 408-425. [CrossRef]

105. Zemigala, M. Tendencies in research on sustainable development in management sciences. J. Clean. Prod. 2019, 218, 796-809. [CrossRef]

106. Giddings, B.; Hopwood, B.; O’Brien, G. Environment, economy and society: Fitting them together into sustainable development. Sustain. Dev. 2002, 10, 187-196. [CrossRef]

107. Christmann, P. Multinational Companies and the Natural Environment: Determinants of Global Environmental Policy. Acad. Manag. J. 2004, 47, 747-760. [CrossRef]

108. Zhu, Q.; Sarkis, J.; Lai, K. Institutional-based antecedents and performance outcomes of internal and external green supply chain management practices. J. Purch. Supply Manag. 2013, 19, 106-117. [CrossRef]

109. Buzan, T. Mapy Myśli; JK Wydawnictwo: Łódź, Poland, 2007; ISBN 978-83-7229-145-5.

110. Szarucki, M. Model of Method Selection for Managerial Problem Solving in an Organization. Bus. Manag. Educ. 2013, 11, 168-187. [CrossRef]

111. Sugawara, E.; Nikaido, H. Properties of AdeABC and AdeIJK efflux systems of Acinetobacter baumannii compared with those of the AcrAB-TolC system of Escherichia coli. Antimicrob. Agents Chemother. 2014, 58, 7250-7257. [CrossRef]

112. Matwiejczuk, R.; Tłuczak, A. Wpływ koncepcji logistyki na rozwój krótkich łańcuchów dostaw w sektorze rolno-spożywczym. Gospod. Mater. Logistyka 2020, 2020, 13-21. [CrossRef]

113. Jeppesen, L.B.; Molin, M.J. Consumers as co-developers: Learning and innovation outside the firm. Technol. Anal. Strateg. Manag. 2003, 15, 363-383. [CrossRef]

114. Gales, L.; Mansour-Cole, D. User involvement in innovation projects: Toward an information processing model. J. Eng. Technol. Manag. 1995, 12, 77-109. [CrossRef]

115. Kumar, V.; Rajan, B.; Gupta, S.; Pozza, I.D. Customer engagement in service. J. Acad. Mark. Sci. 2019, 47, 138-160. [CrossRef]

116. Cronin, J.J.; Brady, M.K.; Hult, G.T.M. Assessing the effects of quality, value, and customer satisfaction on consumer behavioral intentions in service environments. J. Retail. 2000, 76, 193-218. [CrossRef] 